\title{
Emissões otoacústicas e sistema olivococlear medial: pacientes com zumbido sem perda auditiva ${ }^{* * *}$
}

\author{
Otoacoustic emissions and medial olivocochlear system: patients \\ with tinnitus and no hearing loss
}

Rita Mor* (contato@ritamor.com)

Marisa Frasson de Azevedo**

*Fonoaudióloga. Mestre em Distúrbios da Comunicação Humana - Campo Fonoaudiológico - Universidade Federal de São Paulo - Escola Paulista de Medicina. Professora e

Coordenadora dos Estágios Práticos em Audiologia do Centro de Especialização em Fonoaudiologia Clínica (Cefac)

**Fonoaudióloga. Professora Doutora Adjunto da Disciplina dos Distúrbios da Audição do Departamento de Otorrinolaringologia e Distúrbios da Comunicação Humana da Universidade Federal de São Paulo - Escola Paulista de Medicina. Professora Adjunto da Universidade Federal de São Paulo Escola Paulista de Medicina.

***Trabalho Realizado no Centro de Especialização em Fonoaudiologia Clínica.

Artigo de Pesquisa

Artigo Submetido a Avaliação por Pares

Conflito de Interesse: não

Recebido em 06.12.2004

Revisado em 28.03.2005; 16.08.2005 8.11.2005

Aceito para Publicação em 8.11.2005

\section{Abstract}

Background: tinnitus. Aim: to compare the results of otoacoustic emissions for transitory stimulus (TEOAE) and the functioning of the olivocochlear medial system, in individuals with normal hearing sensibility, with and without tinnitus. Method: participants of this study were 60 subjects, with tonal thresholds and acoustic imitance measurements within normal standards, distributed in two groups: group one - 30 subjects with tinnitus and group two - 30 subjects without tinnitus, paired up by gender and age. Both groups were submitted to the TEOAE test, with and without the presence of white contralateral white noise at $60 \mathrm{~dB}$ NPS. For the 19 subjects who presented unilateral tinnitus, TEOAE and suppression results were compared regarding the variables of side, taking in consideration the presence of tinnitus. Results: in the group comparison, with and without tinnitus, there was no significant statistical difference for the incidence of TEOAE, response levels, and incidence of the suppression effect. Significant statistical difference was not observed between the right and left ears in the group with tinnitus. For the 19 subjects with unilateral tinnitus, a higher amplitude of the responses and a higher suppression incidence were observed for the right ear, as well as a higher incidence of tinnitus and a lower incidence of suppression for the left ear. Conclusion: there was no significant statistical difference for both TEOAE incidence and response levels, as well as for the functioning of the olivocochlear medial system between the subjects, with normal hearing sensibility, with and without tinnitus. For the subjects who presented unilateral tinnitus, the overall TEOAE reponse levels was significantly higher in the ear with no tinnitus and the olivocochlear medial system was significantly less efficient in the ear with tinnitus.

Key Words: Hearing; Auditory Pathways; Spontaneous Otoascoustic Emission; Tinnitus.

\section{Resumo}

Tema: zumbido. Objetivo: comparar os resultados das emissões otoacústicas transitório por estímulo (EOAT) e do funcionamento do sistema olivococlear medial, em indivíduos com sensibilidade auditiva normal, com e sem zumbido. Método: a casuística deste estudo foi composta por 60 sujeitos, com limiares tonais e medidas da imitância acústica dentro dos padrões da normalidade distribuídos em dois grupos: grupo um formado por 30 sujeitos com zumbido e grupo dois por 30 sujeitos sem zumbido, pareados por gênero e idade. Os dois grupos foram submetidos ao teste das EOAT com e sem ruído branco contralateral a 60dB NPS. Em 19 sujeitos que apresentavam zumbido unilateral comparou-se os resultados das EOAT e supressão em relação à variável lado, considerando-se o lado do zumbido. Resultados: na comparação entre os grupos com e sem zumbido não houve diferença estatisticamente significante quanto à ocorrência das EOAT, à amplitude de resposta, e à ocorrência do efeito de supressão. Não se observou diferença estatisticamente significante entre as orelhas direita (OD) e esquerda (OE) no grupo com zumbido. Nos 19 sujeitos com zumbido unilateral, observou-se maior amplitude de resposta e maior ocorrência de supressão à direita e maior ocorrência de zumbido e menor ocorrência de supressão à esquerda. Conclusão: não houve diferença estatisticamente significante tanto na ocorrência e amplitude de respostas das EOAT quanto no funcionamento do sistema olivococlear medial entre os sujeitos, com sensibilidade auditiva normal, com e sem zumbido. Nos sujeitos que apresentaram zumbido unilateral, observou-se que a amplitude geral das EOAT foi maior na orelha sem zumbido e que o sistema olivococlear medial foi menos eficiente na orelha com zumbido de forma estatisticamente significante.

Palavras-Chave: Audição; Vias Auditivas; Emissões Otoacústicas Espontâneas; Zumbido. 


\section{Introduction}

In accordance with the National Institute of Health, tinnitus is a very frequent symptom, affecting about $15 \%$ of the American people (Sanchez and Ferrari, 2004). A study concerning the prevalence of tinnitus in a random sample of a Brazilian capital, concluded that $25 \%$ of the investigated subjects presented this complaint and among them, $45 \%$ were men and $55 \%$ women (Gomes et al, 2004). Another study points out to the increase of tinnitus with aging and to the higher susceptibility of the feminine gender (Baguley, 2002).

Before being an illness, tinnitus is a symptom that always reflects some underlying abnormality. The patient bearer of this symptom must always be submitted to medical assessment for the diagnosis and treatment of possible underlying pathology (Sanchez, 2002; Sanchez et al, 2002). It may almost always be associated with a hearing loss, but it can also occur in patients with normal hearing (Sanchez e Ferrari, 2004). As it is considered a ghost feeling, only noticed by the patient, it is difficult to be measured.

The action of the outer hair cells has a crucial role in the hearing sensitivity, in the frequencies selectivity and in the increase of the dynamic hearing scale; the rigid coupling of the hair cells' hair to the tectorial membrane is necessary for the normal cochlear functioning (Withnell et al, 2002). An enormous variety of central or peripheral hearing dysfunctions may become tinnitus (Kompis et al, 2004). Stress and anxiety may alter the biochemistry of the central auditory system, which might be related to mechanisms that generate the tinnitus (Sahley and Nodar, 2001).

The hearing assessment is the first and more important step for investigating tinnitus because it sets forth the base from which the clinical and/or surgical procedures will be supported on. The speech pathologist has an important role in the multidisciplinary team in charge of the evaluation, diagnosis, intervention strategies development and treatment.

The otoacoustic emissions result from the activity of outer hair cells and therefore they are useful for differentiating cochlear disturbances (Hood and Berlin, 2002). The outer hair cells have proper activity that is reflected in the capacity of two contraction types, quick and slow, as they are active cochlear effectors due to such electromotility (Kemp, 2002). This energy may be captured by using a PC with a small probe adapted to the external auditory meatus in a fast and non-invasive mode. Many authors attempt to explain some aspects related to tinnitus by proposing the use of otoacoustic emissions as a resource that assists the topodiagnostic of hearing disorders. The otoacoustic emissions can be classified as spontaneous or evoked, according to their generating stimulus. The largest subclass of evoked otoacoustic emissions is called Transitory Evoked Otoacoustic Emissions (TEOAE) because they are triggered by using a very short acoustic stimulus and, as it concerns a broadband signal, the entire cochlea is activated. Their presence may confirm the integrity of the cochlear mechanism since they will be absent when the hearing sensibility as a whole is lowered in 25 or 30 dBHL (Bonfils et al., 1998; Glattke and Robinette, 2002; Lopes Filho and Carlos, 2005).

TEOAE can be an important instrument for early detection of cochlear dysfunctions, because there may be a diffuse lesion in more than $30 \%$ of the outer hair cells before the detection of any hearing loss (Bohne and Clark, 1982, Fiorini and Fisher, 2000).

The mechanical movement of the outer hair cells is controlled by the efferent olivocochlear system described by Rasmussen in 1946. This system includes two bundles: the lateral, composed by non-myelin sheath fibers, is ipsilateral and projected from the lateral area of the superior olivary complex to the inner hair cells; the medial, composed by myelin sheath fibers, is projected ipsilaterally and contralaterally from the medial area of the superior olivary complex to the outer hair cells. The medial efferent olivocochlear system can be activated by electric, chemical or noise stimulations and, thus, it inhibits the contractions of the outer hair cells, reducing the amplitude of the otoacoustic emissions. It has important hearing implications, such as, the subject's capacity to detect a signal in the noise; tuning the frequency selectivity; protection against acoustic superstimulation; focusing the attention on an acoustic phenomenon; adjusting the cochlear amplification functioning as a dumper during the amplification for a better reception of the sound stimulus by the inner hair cells (Liberman and Kujawa, 1999; Azevedo, 2003).

A simple method to study the functioning of this system is through the comparison between the TEOAE amplitude with and without contralateral acoustic stimulation (Berlin et al, 1994; Berlin et al, 1996; Lopes Filho and Carlos, 2005). 
Several studies investigated the TEOAE suppression effect in subjects with no hearing dysfunction or complaints; they used contralateral broadband noise at 50 dBNPS as stimulus, and their results evidenced a suppression effect greater than $1 \mathrm{~dB}$ in $90 \%$ of the ears. The variation range was between 0.1 to 5.5 dBSPL (Ryan e Kemp, 1996; Rabinovich, 1999; Bernardi, 2000).

The relationship between efferent hearing pathways and tinnitus has been raised for several years. A dysfunction of the efferent hearing pathways could be involved with tinnitus production and perception. Studies in subjects with tinnitus show a less effective TEOAE suppression with the contralateral stimulus than subjects with no tinnitus (Breuel et al, 2001; Samelli and Schochat, 2002; Favero et al, 2004). However, other investigations concluded that there was no settled rule between tinnitus genesis and the efferent hearing pathways' activity (Chéry-Croze et al, 1994).

Some studies have reported an improvement of tinnitus after adapting hearing prosthesis (Ferrari et al, 2003; Siqueira and Assencio-Ferreira, 2002) and tinnitus habituation therapy (TRT - Tinnitus Retraining Therapy). Bartnik et al 2001 observed improvement in $70 \%$ of the patients with tinnitus after one year therapy.

This way, considering the studies that mention the cochlea as one of the probable locations where tinnitus is generated, that it can be evaluated through the otoacoustic emissions, and the role of the medial olivocochlear system in the contraction of outer hair cells, the purpose of this study was to compare the findings of otoacoustic emissions in patients with normal hearing sensibility with and with no tinnitus, by evaluating:

1. TEOAE results.

2. The medial olivocochlear system functioning.

\section{Method}

A group of 30 subjects (60 ears), 27 female and 3 male, ranging in age from 20 to 64 years old, was selected among the patients refferred by a Public Otolaryngology Service to the Audiology Outpatients Clinic of Clinic-School - CEFAC (Clinical Audiology and Speech Pathology Specialization Center) for hearing evaluation. The inclusion criteria for the study were as follows: the patients should present tinnitus complaint, however, hearing thresholds below or equal to 20 $\mathrm{dBHL}$ in the frequency range between 250 and 8000 $\mathrm{Hz}$ (ASHA 1978), and the acoustic imitance measures should be type A timpanometry (Jerger et al, 1972; Carvallo, 2004) and presence of contralateral acoustic reflexes. The subjects were then informed about the investigation and the voluntary nature of their participation, and signed the Informed Consent Term for participating in the study and for allowing the publication of the results , according to the current ethical rules of the Federal University of São Paulo (UNIFESP) and approved by the Research Ethics Committee CEP $0028 / 02$. This group was identified as "Study Group".

The Control Group was composed by 30 subjects, being 27 female and 3 male, ranging in age from 19 to 62 years, selected among volunteers with no complaints or hearing loss.

Therefore, 60 subjects were studied distributed in two groups paired by gender and age in order to avoid possible bias in the results variation analysis. The subjects underwent the following procedures:

1. Anamnesis: for collecting general information and information concerning the tinnitus characteristics were collected.

2. Meatoscopy: for identifying wax presence that might impede the exams.

3. Pure tone audiometry: a Grason Stadler GSI 61 audiometer was used. Such equipment allows to obtain tonal thresholds in the frequencies from 250 to $20000 \mathrm{~Hz}$ and it is in accordance with the ANSI S3, 6 - 1989; ANSI S3, 43 - 1992; IEC 645-1 (1992); IEC 645-2 (1993); ISSO 389; UL 544 standards. A conventional audiometry was carried out in the frequencies from 250 to $8000 \mathrm{~Hz}$, with varying intensity levels from -10 to $120 \mathrm{dBHL}$, with a TDH 50P Telephonics earphones.

4. Acoustic imitance measures: the meddle ear analyzer AZ-7 Interacoustics model was used, calibrated in such a way to meet the manufacturer's technical specifications.

5. Cochlear Emission Analyzer - ILO 292 OTODYNAMICS Analyser: for carrying out the Transitory Otoacoustic Evoked Emissions (TEOAE), the computer program ILO 292Otodynamics Analyser was used, connected to a Pentium notebook. The equipment has a probe (ILO Type OAE Probe) with the function of releasing the sound stimulus, receiving and measuring the answer in the external auditory meatus (MAE). This probe is connected to two channels and to an interface coupled to a PC. The test began with the "checkfit" that consists of verifying the probe's adaptation in the MAE. This step is visualized on 
the PC screen, starting up the probe's set up condition and the characteristics of the hearing stimulus to be provided. Non-linear clicks were used as stimulus for obtaining the recordings (in each series of four clicks, three have the same polarity and one has inverse polarity) with regular pulses of 80 micro-seconds, having rarefaction polarity and repetition frequency of 50 cycles a second (cps). A series of 260 stimuli was presented in blocks of eight clicks in each testing situation, according to the non-linear technique proposed by Kemp et al, 1990. There was a concern with a good probe fit by using a foam probe, so that the emissions would be properly recorded. The click intensity was between 78 and $83 \mathrm{~dB}$ pe NPS. As for the emissions spectrum, the standard stimulus contains energy distributed between 0.5 and $5 \mathrm{kHz}$, providing information on a wide frequency range. The analysis criteria for considering the presence of the emissions were: stability of the probe should above $80 \%$, and the emissions' reproductibility above $70 \%$ (Hood et al, 1996).

6. TEOAE suppression effect measure: to measure it, the TEOAE were initially registered in the absence of contralateral noise and, then, introducing white noise in the intensity of 60 dBSPL emitted by the GSI 61 audiometer through the TDH 50P earphone in the contralateral ear, as recommended by Collet, 1992.

That analysis was always accomplished after the analysis with no contralateral stimulus, in both ears, aiming at not altering the placement of the probe during both test situations, so that the following sequence was observed: TEOAE in the right ear in the absence of contralateral white noise and then in the presence of contralateral white noise; TEOAE in the left ear in the absence of contralateral white noise and then in the presence of contralateral white noise.

The suppression effect was verified through the observation of the general amplitude variation in the presence of noise in relation to the general amplitude without noise. The value of the suppression referring to the olivocochlear system action is given by the difference of the values obtained in the conditions with and without contralateral stimulus, in each ear, and that value determines if there is or there isn't suppression, that is, if the value is positive, there is suppression and if it is negative or equal to zero, there is no suppression in the emissions amplitude (Hood et al, 1996; Ryan and Kemp, 1996; Rabinovich,1999; Bernardi, 2000; Samelli and Schochat, 2002). In this study a minimum variation of $0.5 \mathrm{dBSPL}$ was considered.

All the exams were accomplished in acoustic cabins located in acoustically treated rooms in just one day.

Data analysis and statistical analysis.

To enable a more reliable data analysis between the groups with and without tinnitus, the two groups were compared and submitted to a statistical treatment by means of SPSS (Statistical Package is Social Sciences) in its 10.0 version. The significance level considered was $5 \%(0,050)$, which is statistically significant when the value of the calculated significance (p) is lower than the level of adopted significance (5\%).

\section{Results}

The study aimed at verifying if there was any difference in the presence of TEOAE between the groups with and without tinnitus. In spite of the study group presenting lower occurrence of TEOAE (Graphs 1 and 2), the differences found were not statistically significant (Tables 1 and 2).

The study observed that there was no significant statistical difference when comparing the amplitude of the EOE between the groups with and without tinnitus, both in the general response as well as in the frequency bands for the right and left ears (Tables 3 and 4).

No significant statistical difference was found concerning the suppression occurrence between the groups with and without tinnitus (Table 5).

There was no significant statistical difference between the mean values of the differences concerning the general response amplitude (A) in the situations with and with no white noise between the study and control groups for the right ear and left ear (Table 6).

TABLE 1.Calculated value (p) referring to the analysis of the presence of response (\%), for the general response's amplitude (A) and in the frequencies from 1 to $5 \mathrm{kHz}$ in the right ear in the study and control groups $(\mathrm{n}=30)$ (Student $t$ test for proportions).

\begin{tabular}{ccc|ccc|c} 
& $\mathrm{A}$ & 1000 & 2000 & 3000 & 4000 & 5000 \\
\hline estudo & 30 & $19(63 \%)$ & $21(70 \%)$ & $17(57 \%)$ & $15(50 \%)$ & $7(23 \%)$ \\
controle & $28(93 \%)$ & $20(67 \%)$ & $24(80 \%)$ & $20(67 \%)$ & $21(70 \%)$ & $7(23 \%)$ \\
$\mathrm{p}$ & 0,161 & 0,791 & 0,380 & 0,434 & 0,118 & 1,0 \\
\hline
\end{tabular}


TABLE 2. Calculated value (p) referring to the analysis of the presence of response (\%), for the general response amplitude (A) and in the frequencies from 1 to $5 \mathrm{kHz}$ in the left ear in the study and control groups $(\mathrm{n}=30)$ (Student t test for proportions).

\begin{tabular}{ccc|ccc|c} 
& $\mathrm{A}$ & 1000 & 2000 & 3000 & 4000 & 5000 \\
\hline estudo & $26(87 \%)$ & $18(60 \%)$ & $21(70 \%)$ & $16(53 \%)$ & $13(43 \%)$ & $8(27 \%)$ \\
controle & $29(97 \%)$ & $19(63 \%)$ & $23(77 \%)$ & $21(70 \%)$ & $20(67 \%)$ & $10(33 \%)$ \\
$\mathrm{p}$ & 0,168 & 0,795 & 0,567 & 0,190 & 0,071 & 0,581 \\
\hline
\end{tabular}

TABLE 3. Mean values (mean and standard deviation) of the TEOAE response amplitudes (A) and of the frequencies from 1 to $5-\mathrm{kHz}$ of study and control groups for the right ear (Student t test).

\begin{tabular}{ccc|ccc|c} 
& $\mathrm{A}$ & 1000 & 2000 & 3000 & 4000 & 5000 \\
\hline estudo & $\begin{array}{c}12,4 \pm \\
4,7\end{array}$ & $5,3 \pm 4,9$ & $5,6 \pm 4,9$ & $4,3 \pm 4,9$ & $4,6 \pm 5,6$ & $1,8 \pm 3,6$ \\
& $11,5 \pm$ & $4,6 \pm 4,0$ & $5,9 \pm 4,1$ & $5,2 \pm 4,1$ & $4,4 \pm 3,9$ & $1,2 \pm 2,4$ \\
controle & 4,6 & 0,566 & 0,756 & 0,447 & 0,893 & 0,429
\end{tabular}

TABLE 4. Mean values (Mean and standard deviation) of TEOAE response amplitudes (A) and of the frequencies from 1 to $5-\mathrm{kHz}$ of study and control groups for the left ear (Student t test).

\begin{tabular}{|c|c|c|c|c|c|c|}
\hline & A & 1 & 2 & 3 & 4 & 5 \\
\hline estudo & $\begin{array}{c}10,5 \pm \\
5,6\end{array}$ & $4,3 \pm 4,1$ & $6,2 \pm 5,0$ & $3,7 \pm 4,7$ & $3,1 \pm 4,2$ & $1,3 \pm 2,4$ \\
\hline controle & $\begin{array}{c}12,2 \pm \\
4,7\end{array}$ & $4,8 \pm 4,7$ & $5,9 \pm 4,8$ & $5,7 \pm 5,3$ & $4,8 \pm 4,9$ & $2,4 \pm 4,6$ \\
\hline $\mathrm{p}$ & 0,220 & 0,619 & 0,834 & 0,130 & 0,159 & 0,223 \\
\hline
\end{tabular}

The group with tinnitus showed lower response's differences in the situations with and without contralateral noise on the left side, however, they were not statistically significant (Table 7).

The study aimed at verifying if there was any relationship between the tinnitus side and the TEOAE amplitude and the suppression effect. Therefore, 19 patients presenting unilateral tinnitus were studied. In spite of the small sample, it was possible to accomplish some tests that should be considered just as indications of a possible real result.

The application of the Student's $t$ test for proportions was not statistically significant $(\mathrm{p}=$ 0.344 ) when comparing the number of patients presenting tinnitus in the left ear (11) and those presenting it in the right ear (8).

The comparison between the ears for the variables general response amplitude (A), suppression and the difference between them evidenced statistically significant differences in the amplitude of EOE (higher in the right ear) and in the difference between them (in the situation with and without noise, higher in the right ear - Table 8).

The relationship between the side of the tinnitus and the lowest suppression $(p=0,013 *)$ was then compared, that is, among the subjects with tinnitus in the right ear, five presented lower difference in the right ear and two in the left ear; among the subjects with tinnitus in the left ear, one presented lower difference in the right ear and ten in the left ear (Table 9). This analysis considered only the individuals who presented TEOAE in both ears and, therefore, one of the subjects who did not present TEOAE in the ear with tinnitus had to be excluded $(\mathrm{n}=18)$.

TABELA 5. Occurrence of the suppression effect for the right and left ears in the study and control groups (Student $\mathrm{t}$ test for proportions).

\begin{tabular}{ccc} 
& Orelha Direita & Orelha Esquerda \\
\hline estudo & $16(53 \%)$ & $18(60 \%)$ \\
controle & $23(77 \%)$ & $22(73 \%)$ \\
$\mathrm{p}$ & 0,060 & 0,281 \\
\hline
\end{tabular}

TABLE 6. Mean values (mean and standard deviation) of the differences obtained between general response's amplitudes (A) with and without contralateral white noise, between the study and control groups for the right ear (Student $t$ test).

\begin{tabular}{ccccc} 
& \multicolumn{2}{c}{ Orelha Direita } & \multicolumn{2}{c}{ Orelha Esquerda } \\
& A & Desvio Padrão & A & Desvio Padrão \\
estudo & 2,6 & $\pm 5,0$ & 0,7 & $\pm 1,7$ \\
controle & 1,9 & $\pm 2,2$ & 1,9 & $\pm 3,0$ \\
$\mathrm{p}$ & 0,550 & & 0,063 & \\
\hline
\end{tabular}


TABLE 7. Calculated Mean values of the difference between the response amplitude with and without white noise for the study group regarding the variable side (Student $t$ test).

\begin{tabular}{cc} 
& Estudo \\
\hline Orelha direita & $2,6( \pm 5,0)$ \\
Orelha esquerda & $0,7( \pm 1,7)$ \\
$\mathrm{P}$ & 0,084 \\
\hline
\end{tabular}

TABLE 8. Comparison between RE and LE, for the variables TEOAE general response amplitude (A), suppression and the difference between them.

\begin{tabular}{c|cc|c} 
Variável & Orelha Direita & Orelha Esquerda & Significância (p) \\
A & $12,5 \pm 4,8$ & $10,6 \pm 6,2$ & $0,041^{*}$ \\
supressão & $9,0 \pm 6,4$ & $10,2 \pm 5,7$ & 0,439 \\
diferença & $3,5 \pm 5,5$ & $0,4 \pm 1,8$ & $0,048^{*}$ \\
\hline
\end{tabular}

Aplicação do Teste t de Student para Dados Pareados.

TABLE 9. Study about the relationship between the side of the tinnitus and the side of the lowest difference observed (between general response amplitude value and the suppression value).

\begin{tabular}{c|ccc}
\multirow{2}{*}{ Zumbido } & \multicolumn{2}{|c}{ Menor Diferença } & TOTAL \\
& À Direita & À Esquerda & \\
Orelha Direita & $5(27,8 \%)$ & $2(11,1 \%)$ & $7(38,9 \%)$ \\
Orelha Esquerda & $1(5,6 \%)$ & $10(55,6 \%)$ & $11(61,1 \%)$ \\
TOTAL & $6(33,3 \%)$ & $12(66,7 \%)$ & $18(100 \%)$ \\
\hline
\end{tabular}

Legenda: Aplicação do Teste de Fisher - p = 0,013*.

GRAPH 1. Occurrence of responses for frequencies from 1000 to $5000-\mathrm{Hz}$ in the right ear of study and control groups.

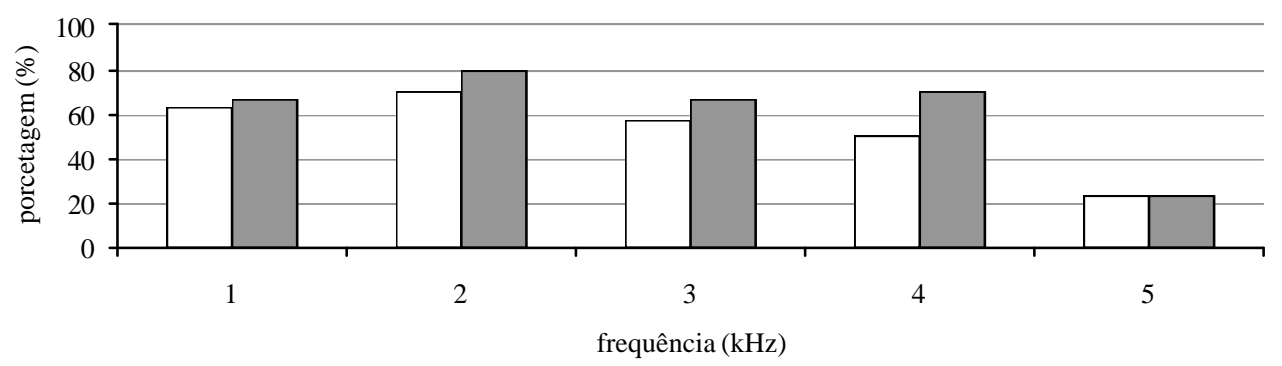

$\square$ estudo $\square$ controle 
GRAPH 2.Occurrence of responses for frequencies from 1000 to $5000-\mathrm{Hz}$ in the left ear of study and control groups.

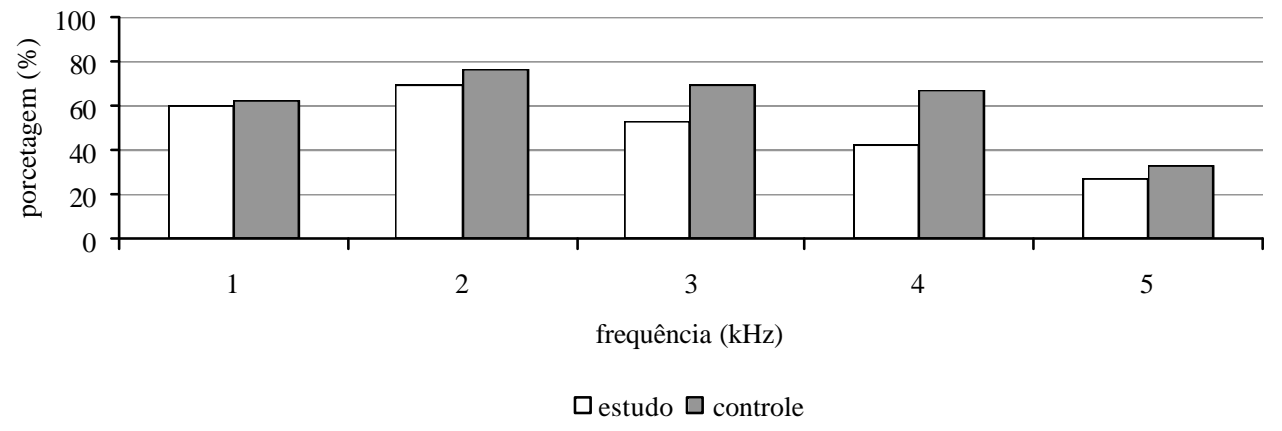

\section{Discussion}

According to the literature descriptions, the presence of otoacoustic emissions indicates total or partial cochlear integrity. Regarding this work's subjects, either in the group with tinnitus (study group) or in the group without tinnitus (control group), the hearing thresholds, up to the frequency of $8000 \mathrm{~Hz}$, were always below $20 \mathrm{dBHL}$.

This study evidenced the occurrence of EOE in more than $90 \%$ of the control group and from 87 to $100 \%$ in the study group (Tables 1 and 2). This finding is similar to other studies that found presence of response in most of the studied subjects with no otological complaints and whose hearing thresholds did not exceed $20 \mathrm{dBHL}$ (Bonfils et al., 1998; Aita, 2001, Lopes Filho and Carlos, 2005).

Moreover, using the same criterion of hearing thresholds, some authors found TEOAE present in percentages varying between $50 \%$ and $72.5 \%$ (Fiorini and Fisher, 2000; Bernardi, 2000; Samelli and Schochat, 2002). Some justifications, such as anatomical alterations of external acoustic meatus or middle ear (it is extremely important that the eardrum and ossicular chain are entirely normal), problems related to the equipment or noises, are presented to explain the absence of TEOAE (Lopes Filho e Carlos, 2005).

The occurrence of TEOAE was lower in the patients with tinnitus, but, not statistically significant. This result is similar to a study of Samelli and Shochat (2002) that compared the occurrence of response in subjects with and with no tinnitus, however, with a hearing loss starting from $2000 \mathrm{~Hz}$. Pospiech et al, (2003) found absence of otoacoustic emissions in patients with tinnitus and hearing thresholds of up to $25 \mathrm{dBHL}$, however, he used EOE distortion product (EOE - DP).
The frequency analysis carried out in this study showed a basically uniform occurrence of response among the frequencies from 1000 to $4000 \mathrm{~Hz}$, with a decrease in $5000 \mathrm{~Hz}$ in both groups (Graphs 1 and 2). Bernardi (2000) found in the comparison between the ears of a sample group with no otological complaints nor hearing loss, a larger decrease of the left ear responses in the frequencies of 3000 and $4000 \mathrm{~Hz}$ in relation to the right ear, however, not significant.

The comparison of mean values of the TEOAE general response amplitude between the study and control groups for the right and left ears, did not show any significant statistical difference (Tables 3 and 4). Samelli and Schochat (2002) observed similar results in their study.

The Mean value of general response's amplitude between the ears of the two groups was between 10.5 and 12.4 dBSPL (Tables 3 and 4), similar to the values described by Bernardi (2000) in adult population.

It was verified in this study a high variability between the values of the TEOAE general response amplitude in the situations with and without the presence of contralateral white noise, varying from their non-reduction to their increase. In the study group, the values were between -5.3 and 15.3 dBSPL in the right ear and -4.1 and $3.2 \mathrm{dBSPL}$ in the left ear, and in the control group between $-3,2$ and 9.1 $\mathrm{dBSPL}$ in the right ear and -1.5 and $12.3 \mathrm{dBSPL}$ in the left ear. Other researchers (Collet et al, 1992; Ryan and Kemp, 1996) also found a large range of individual variability when there is a contralateral acoustic stimulation.

For many years the relationship between the efferent hearing pathways and the tinnitus has been investigated. Among the mechanisms of 
generation and perception of the tinnitus, it is postulated that an input decrease of the hair cells pertaining to the basilar membrane portion may result in a decrease of activity of the efferent fibers and the inhibition of the afferent pathways coming from the inner hair cells. That will accentuate the activation of normal inner hair cells, resulting in an abnormal activity deemed as tinnitus (Hood et al., 1996). After observing the non-reduction of TEOAE amplitude in patients with of multiple sclerosis, Rabinovich (1999) recommends the study of the hearing pathway as a whole in the prevention of retrocochlear pathology. The study of the TEOAE suppression would allow knowing the interaction between the afferent and efferent pathways and to distinguish between cochlear and retrocochlear hearing losses.

Alterations in the efferent hearing system with lower suppression of emissions were described in subjects with tinnitus by Samelli and Schochat (2002) and Favero et al (2004). Similarly, this study verified that the group with tinnitus presented lower occurrence of suppression $(53 \%$ in the right ear and $60 \%$ in the left ear) when compared to the control group $(77 \%$ in the right ear and $73 \%$ in the left ear). However, the difference between such values was not statistically significant, despite the study result for the right ear indicating a value very close to the significance value adopted (Table 5).

Based on the results presented in Tables 6 and 7 , it was verified that the TEOAE suppression value in the study group was $2.6 \mathrm{dBSPL}$ in the right ear and $0.7 \mathrm{dBSPL}$ in the left ear, and in the control group 1.9 dBSPL in both ears. Again the statistical analysis did not reveal significant difference, but was a lot close in relation to the lowest suppression in the left ear, both in the comparison between the two groups as well as in relation to the study group.

In order to establish a more effective relationship between the olivocochlear system operation and the tinnitus, this study compared the suppression of otoacoustic emissions of 19 subjects' ears from the group with unilateral tinnitus (study). Of those, 11 presented tinnitus in the left ear and 08 in the right ear. The comparison of the proportion between the number of patients presenting tinnitus in the left ear $(57 \%)$ and those presenting it in the right ear $(\mathrm{p}=0,344)$ had no statistical significance $(\mathrm{p}=0.344)$.

The comparison between general response amplitude and the suppression, observed between the right and left ears, showed that there is a significant statistical difference with a prevalence of the right ear (Table 8). A possible hypothesis for explaining such alteration would be the fact that the efferent hearing system functions laterally, following the patterns of hemispheric predominance (Khalfa et al, 1997). Coincidentally, the subjects with unilateral tinnitus were righthanders.

The comparison between the tinnitus side and the lowest difference value noted in our study, was statistically significant (Table 9) and it corroborates other researches that found the olivocochlear system less effective on the tinnitus side (Collet et al, 1992; Chéry- Croze et al, 1994; Samelli and Schochat, 2002; Favero et al, 2004).

Comparing the findings regarding the suppression effect of the group without tinnitus (control) of our study in relation to others with the same population, also allows to point out some similarities and differences among them, that would be explained by the inter-individual variability referring to the recorded emissions, once that they are unique for each ear, differing in the frequencies as well as in the amplitudes (Ryan and Kemp, 1996). In this study, the occurrence of suppression $(73 \%$ and $77 \%$ ) was below the values obtained in the literature that are between 92.5 and $100 \%$ of suppression (Hood et al, 1996; Rabinovich, 1999; Bernardi, 2000). Such differences may be due to the fact that the authors considered values between 0.1 and $0.33 \mathrm{dBNPS}$ as the minimum value for the occurrence of the suppression effect, while this study considered the value equal or above 0.5 dBSPL. As for the reduction of the suppression effect, an average of $1.9 \mathrm{dBSPL}$ was verified in the right and left ears (Table 6), therefore, similar to the described in researches with subjects without hearing loss (Hood et al, 1996; Ryan and Kemp, 1996; Rabinovich, 1999).

\section{Conclusion}

From this study it was possible to conclude that there was no statistical significant difference both in the incidence and amplitude of TEOAE as well as in the functioning of the medial olivocochlear system between the subjects with normal hearing sensibility, with and without tinnitus. In the subjects who presented unilateral tinnitus, the general amplitude of TEOAE responses was statistically higher in the ear without tinnitus and the medial olivocochlear system was statistically less efficient in the ear with tinnitus. 


\section{References}

AITA, A. D. C. Capacidade e autopercepção auditivas: um estudo em hiperacúsicos. 2001. 164 f. Tese (Doutorado em Distúrbios da Comunicação Humana) - Universidade Federal de São Paulo. Escola Paulista de Medicina.

AMERICAN SPEECH LANGUAGE-HEARING ASSOCIATION - Manual pure-tone threshold audiometry. $A S H A$, v 20, n 4, p 297-301, 1978.

AZEVEDO, M. F. Emissões otoacústicas. In: FIGUEIREDO, M. S. Conhecimentos essenciais para entender bem emissões otoacústicas e bera. São José dos Campos: Pulso, 2003. p 11-34.

BAGULEY, D. M. Mechanisms of tinnitus. British Medical Bulletin, v. 63, p. 195-202, 2002.

BARTNIK, G. FABIJANSKA, A. ROGOWISKI, M. Experiences in the treatment of patients with tinnitus and/ or hyperacusis using the habituation method. Scand Audiol., v. 30, n. 52, p 187-190, 2001. Suppl.

BERLIN, C. A.; HOOD, L. J.; HURLEY, A. WEN, H. Contralateral suppression of otoacoustic emissions an index of the function of the medial olivocochlear system. Otolaryngol, Head Neck Surg ., v. 110, n. 1, p. 3-21, 1994.

BERLIN, C. A.; HOOD, L. J.; HURLEY, A.; WEN, H. Hearing aids: only for hearing impaired patients with abnormal otoacoustic emissions. In: BERLIN, C. I. Hearing cells and hearing aids. San Diego: Singular Publishing Group, Inc., 1996. p 3-27.

BERNARDI, A. P. A. Trabalhadores expostos simultaneamente a ruído e tolueno: estudo das emissões otoacústicas evocadas transitórias e efeito de supressão. 2000. $141 \mathrm{f}$. Tese (Mestrado em Epidemiologia) - Universidade de São Paulo, São Paulo.

BOHNE, B. CLARK, W. W. Growth of hearing loss and cochlear lesion with increasing duration of noise exposures. In: HOMENIK, A. P.; HENDERSON, D.; SALVI, R. New perspectives on noise-induced hearing loss. New York: Raven Press, 1982. p. 283-302.

BONFILS, P.; PIRON, J. P., UZIEL, A.; PUJOL, R. A correlative study of evoked otoacoustic emission properties and audiometric thresholds. Arch. Otorhinolaryngol., v 245, p. 53-56, 1998.

BREUEL, M. L. F.; SANCHEZ, T. G.; BENTO, R. F. Vias auditivas eferentes e seu papel no sistema auditivo. Arch. Fund. Otorrinolaringol., v. 5, n. 2, p. 62-67, 2001.

CARVALLO, R. M. M. Imitanciometria. In: FERREIRA, L. P.; BEFFI-LOPES, D. M.; LIMONGI, S. C. O. Tratado de Fonoaudiologia. São Paulo: Rocca, 2004. p. 569-584.

CHÉRY-CROZE, S.; TRUY, E.; MORGON, A. Contralateral suppression of transiently evoked otoacoustic emissions and tinnitus. British Journal of Audiology, v. 28 , p. 255-266, 1994.

COLLET, L.; VEUILleT, E.; BENE, J.; MORGON, A. Effects of contralateral white noise on click - evoked emissions in normal and sensorineural ears: towards an exploration of the medial olivocochlear system. Audiology, v. 31, p. $1-7,1992$.
FAVERO, M.; BENTO, R. F; SANCHEZ, T. G.; NASCIMENTO, A. F. Contralateral suppression of otoacoustic emission in subject with tinnitus. Otolaryngology-Head and Neck Surgery, v. 131, n. 2, p. 260-264, 2004.

FERRARI, G. M. S.; SANCHEZ, T. G.; BERNARDI, A. P. A. Controle do zumbido através do uso de próteses auditivas retro-auriculares. Rev. CEFAC, v. 5, n. 2, p. 169-173, 2003.

FIORINI, A. C.; FISCHER, F. H. Emissões otoacústicas por transiente evocado em trabalhadores expostos a ruído ocupacional. Revista Distúrbios da Comunicação. São Paulo, v. 11, n. 2, p. 167-191, 2000

GLATTKE, T. J.; ROBINETTE, M. S. Transient evoked otoacoustic emissions. In: ROBINETTE, M. S.; GLATTKE, T. J. Otoacoustic emissions: clinical applications. 2. ed. New York: Thieme, 1997. p. 63-82.

GOMES, S. J. V.; BARBOZA, R. M.; SANTOS, T. M. M. A incidência de zumbido numa amostra aleatória na cidade de Salvador. Rev. CEFAC, v. 6, n. 1, p. 89-93, 2004.

HOOD, L.; BERLIN, C. I. Clinical applications of otoacoustic emissions. In: BERLIN, C. I.; HOOD, L. J.; RICCI, A. Hair cell micromechanics and otoacoustic emissions. New York: Thomson Learning, 2002. p. 121-138.

HOOD, L. I.; BERLIN, C. I.; HURLEY, A. H.; WEN, H. Suppression of otoacoustic emissions in humans hearing individuals. In: BERLIN, C. I. Hair cells and hearing aids. San Diego: Singular Publishing Group, 1996. p. 57-72.

JERGER J, JERGER S, MAULDIN L. Studies in impedance audiometry. Arch Otolaryngol., v. 96, p. 513-523, 1972.

KEMP, D. T. Exploring cochlear status with otoacoustic emissions: the potential for new clinical applications. In: ROBINETTE, M. S. GLATTKE, T. J. Otoacoustic emissions: clinical applications. 2. ed. New York: Thieme, 2002. p. 147.

KEMP, D. T.; RYAN, S.; BRAY, P. A guide to the effective use of otoacoustic emissions. Ear Hear., v. 1, n. 2, p. 93-105, 1990.

KHALFA, S.; MORLET, T.; MICHEY, C.; MORGON, A.; COLLET, L. Evidence of peripheral hearing asymmetry in humans: clinical implications. Acta Otolaryngol. (Stockh), v. 117, p. 192-196, 1997.

KOMPIS, M.; NEUNER, N. T.; HEMMELER, W.; HAUSLER, R. Tinnitus. TherUmsch., v. 61, n. 1, p. 15-20, 2004.

LIBERMAN, M. C.; KUJAWA, S. G. The olivocochlear system and protection from acoustic injury: acute and chronic effect. In: BERLIN, C. I. The efferent auditory system-basic science and clinical applications. San Diego: Sing. Pub. Group, 1999. p. 1-27.

LOPES FILHO, O. C.; CARLOS, R. Emissões otoacústicas. In: LOPES FILHO, O. C. Tratado de Fonoaudiologia. São Paulo: Tecmedd, 2005. p. 207-222. 
POSPIECH, L.; SZTUKA-PIETKIEWICZ, A.; JABLONKA, A.; ORENDORZ-FRACZKOWSKA, K. DPOAE otoemission in patients with tinnitus and normal hearing. Otolaryngologia Polska, v. 57, n. 6, p. 905-910, 2003.

RABINOVICH, K. Estudo do efeito de supressão nas emissões otoacústicas evocadas transientes em indivíduos com audição normal e em portadores de esclerose múltipla . 1999. 124 f. Tese (Mestrado em Distúrbios da Comunicação Humana no Campo da Fonoaudiologia) - Universidade Federal de São Paulo, São Paulo.

RASMUSSEN, G. L. The olivary peduncle and other fiber projections of the superior complex. J. Comp. Neurol., v. 84, p. 141-219, 1946.

RYAN, S.; KEMP, D. T. The influence of evoking stimulus level on the neural suppression of transient evoked otoacoustic emissions. Hear Res., v. 94, p. 140-147, 1996.

SAHLEY, T. L.; NODAR, R. H. A biochemical model of peripheral tinnitus. Hear Res., v. 152, p. 43-54, 2001.

SAMELLI, A. G.; SCHOCHAT, E. Estudo das emissões otoacústicas em pacientes com zumbido. Pró-Fono Revista de Atualização Científica, v. 1, n. 14, p. 99-110, 2002.

SANCHEZ, T. G. Reabilitação do paciente com zumbido. In: Tratado de Otorrinolaringologia da sociedade de Otorrinolaringologia. São Paulo: Roca, 2002. p. 311-324. v. 2

SANCHEZ, T. G.; FERRARI, G. M. S. O que é zumbido? In: SAMELLI, A. G. Zumbido - avaliação, diagnóstico e reabilitação. São Paulo: Lovise, 2004. p. 17-22.

SANCHEZ, T. G.; PEDALINI, M. E. B.; BENTO, R. F. Aplicação da terapia de retreinamento do zumbido (TRZ) em hospital público. Arq. Otorrinilaringol., v. 6, n. 1, p 29-38, 2002.

SIQUEIRA, K. L.; ASSENCIO-FERREIRA, V. J. O uso do aparelho de amplificação sonora individual (AASI) no alívio do sintoma zumbido. Rev. CEFAC, v. 4, n. 1, p. 81-86, 2002.

WITHNELL, R. H.; SHAFFER, I. A.; LILLY, D. J. What drives mechanical amplification in the mammalian cochlea? Ear-Hear., v. 23, p. 49-57, 2002. 